Rev. Int. Contam. Ambie. 36 (1) 73-80, 2020

DOI: 10.20937/RICA.2020.36.53201

\title{
STUDY OF THE DEGRADATION OF CHLORPYRIFOS IN CONTAMINATED SOILS IN THE PRESENCE OF THE RED CALIFORNIA EARTHWORM Eisenia foetida
}

Estudio de la degradación de clorpirifos en suelos contaminados en presencia de lombriz roja californiana Eisenia foetida

\author{
Elvis Gilmar GONZALES-CONDORI ${ }^{1}$, Celia CHOQUENAIRA-QUISPE ${ }^{2}$ and \\ Stamber Álvaro RAMÍREZ-REVILLA ${ }^{3 *}$
}

${ }^{1}$ Laboratorio del Proyecto Mercurio, Facultad de Ciencias Farmacéuticas, Bioquímicas y Biotecnológicas, Universidad Católica de Santa María (UCSM), Urb. San José s/n, Umacollo, Arequipa, Perú

${ }^{2}$ Universidad Privada Autónoma del Sur(UPADS), Calle Sebastián Barranca 208, Urb. Santa Isabel, Arequipa, Perú

${ }^{3}$ Universidad Tecnológica del Perú (UTP), Av. Tacna y Arica 160, Arequipa, Perú

*Autor para correspondencia: sramirezr@utp.edu.pe

(Received: March 2018; accepted: June 2019)

Key words: organophosphorus, pollution, remediation, chlorpyrifos, worm

\begin{abstract}
Pesticides containing organophosphorus compounds, such as chlorpyrifos (CPF), are frequently used in agricultural activities, and their use has been increasing due to the presence of multiple plant diseases which threaten the production of vegetable food products. As a result of this practice, the soils in question are often found to be contaminated due to the fact that these pesticides do not immediately degrade and hence remain for long periods of time. The objective of this study was to evaluate the degradation of CPF in the presence and absence of the worm Eisenia foetida (EF) in soils contaminated with $40 \mathrm{mg} / \mathrm{kg}$ of CPF during a 28 -day period. The D group, whose soil was sterilized and in which no EF worms were present, yielded a CPF-degradation result of $33.68 \%$. The $\mathrm{C}$ group, in which the soil was unsterilized and there were no EF worms present, yielded a degradation percentage of $37.16 \%$. On the other hand, the B group, containing sterilized soil in which the EF worms were present, yielded a degradation percentage of $60.76 \%$. Finally, with the A group, in which the soil was unsterilized and EF worms were present, degraded in $74.85 \%$.
\end{abstract}

Palabras clave: organofosforados, contaminación, remediación, clorpirifos, lombriz

\section{RESUMEN}

Los pesticidas que contienen compuestos organofosforados, como clorpirifos (CPF), se utilizan con frecuencia en actividades agrícolas, y su uso ha ido en aumento debido a la presencia de múltiples plagas en plantas, las cuales amenazan la producción de alimentos de origen vegetal. Como resultado de esta actividad, los suelos en estudio se encuentran a menudo contaminados, ya que estos pesticidas no se degradan inmediatamente y por lo tanto permanecen durante largos periodos de tiempo. El objetivo de este estudio, realizado en suelos contaminados con $40 \mathrm{mg} / \mathrm{kg}$ de CPF durante un periodo de 28 días, fue evaluar la degradación de CPF en presencia y ausencia de la lombriz 
Eisenia foetida (EF). En el grupo D, cuyo suelo estaba esterilizado y en ausencia de EF, se obtuvo una degradación del CPF de $33.68 \%$. En el grupo C, donde el suelo no estaba esterilizado y en ausencia de EF, se obtuvo un porcentaje de degradación de $37.16 \%$. Por otro lado, el grupo B, que contenía suelo esterilizado en presencia de EF, mostró un porcentaje de degradación de $60.76 \%$. Finalmente, el grupo A, cuyo suelo no estaba esterilizado y en presencia de EF, se degradó en un $74.85 \%$.

\section{INTRODUCTION}

For many years now, pesticides have brought human beings many benefits in the fields of public health and agriculture, being first-choice resources for different activities due to their use in agriculture in order to combat diseases and thus guarantee the quality as well as quantity of food products. They are likewise used in public health in order to control vectors that spread dangerous epidemics (Schaaf 2013). The pesticides with chemical structures that possess esters of phosphoric acid are referred to as organophosphorus compounds (OP), whose specific pharmacological action is to inhibit acetylcholinesterase in nerve ends, generating an accumulation of acetylcholine and resulting in the alteration of the nerve impulse functions (Fernández et al. 2010).

A wide range of environmental issues have appeared as a consequence of the increase in the use of organophosphorus pesticides (OP) in agricultural practices during the last few years. These chemical substances show a tendency to bioaccumulate through trophic chains; as a result, high levels of toxicity are generated. This situation triggers potential health risks for species that interact with this kind of substances (Marín and Jaramillo 2015). There are three classes of symptoms stemming from organophosphorus-compound poisoning: muscarinic, nicotinic, and central nervous system (CNS) effects. On the other hand, miosis is the most consistent symptom; however, its absence does not necessarily exclude poisoning. These symptoms are also classified according to their levels of severity, i.e., mild, moderate, or acute (Sánchez et al. 2010).

Given that organophosphorus compounds are composed of highly toxic chemicals, their excessive use has caused a massive deterioration of agricultural soils, as well as serious damage to ecosystems and human health. For this reason, bioremediation stands as an alternative to break down pesticides into simpler compounds, thus rendering them less dangerous, through the use of the metabolic potential of microorganisms (Hernández et al. 2017). Studies show that the use of worms considerably increases the degradation of pesticides such as metolachlor (Sun et al. 2019), acetochlor (Hao et al. 2018), and atrazine (Lin et al. 2018) by microbial communities in the soils.

The remediation of contaminated soils using earthworms as well as plants seems to be worthwhile and has proven to be an environmentally-friendly technology. Earthworms improve the structure of the soil, contribute to the decomposition of organic material, and help facilitate the nutrient cycle. Furthermore, they play a vital role in the evaluation of eco-toxicological risks in soils. Nevertheless, the implementation of worms for the purpose of bioremediation is an innovative technique, which has demonstrated the worm's ability to assimilate metals by way of their digestive tracts. It is also known that through their mucilaginous secretions and transformation of organic material, worms increase the activity of microorganisms and the availability of nutrients. Likewise, it has been reported that worms can stimulate bacteria, fungi, and other species related to the degradation of some organic pollutants (Zapata et al. 2017).

Therefore, the objective of this research was to evaluate the degradation of a pesticide containing chlorpyrifos in polluted soils in the presence of the red California earthworm (Eisenia foetida).

\section{MATERIALS AND METHODS}

\section{Determination of chlorpyrifos through high- resolution liquid chromatography}

The equipment utilized in the study was the following: high performance liquid chromatographer (HPLC) Hitachi Chromaster with diode array detector (DAD), Chromolith column RP-18e of $4.6 \times 100$ $\mathrm{mm}$; chlorpyrifos, reference standard $99.5 \%$ from Sigma Aldrich; and acetonitrile, HPLC Merck grade, ACN moving phase: $\mathrm{H}_{2} \mathrm{O}(60: 40)$, flow of $2 \mathrm{~mL} /$ min, $205 \mathrm{~nm}$ wave longitude. The retention time was evaluated, and the method for evaluating linearity, precision, sensitivity, and exactitude was validated (Quattrocchi 1992). 


\section{Extraction of chlorpyrifos from contaminated soils}

Soil sampling was performed by the zig-zag systematic sampling method (Torri et al. 2007). For the extraction of chlorpyrifos from soils, an extraction system (Fig. 1) conditioned with two layers of filter paper and $2 \mathrm{~g}$ of anhydrous sodium sulfite was prepared. Subsequently, $5 \mathrm{~g}$ of the homogenized sample, which was placed in contact with $5 \mathrm{~mL}$ of HPLC-grade acetonitrile, were added. The system was then subjected to ultrasound for $15 \mathrm{~min}$, filtered until empty, and extracted again with another $5 \mathrm{~mL}$ acetronile. The syringe was then washed with 2 additional $\mathrm{mL}$ of acetonitrile. The resulting solution was filtered using a Whatman $45 \mu \mathrm{m}$ nylon filter and then it was read with HPLC (Majzik-Solymos et al. 2001, Castro 2002).

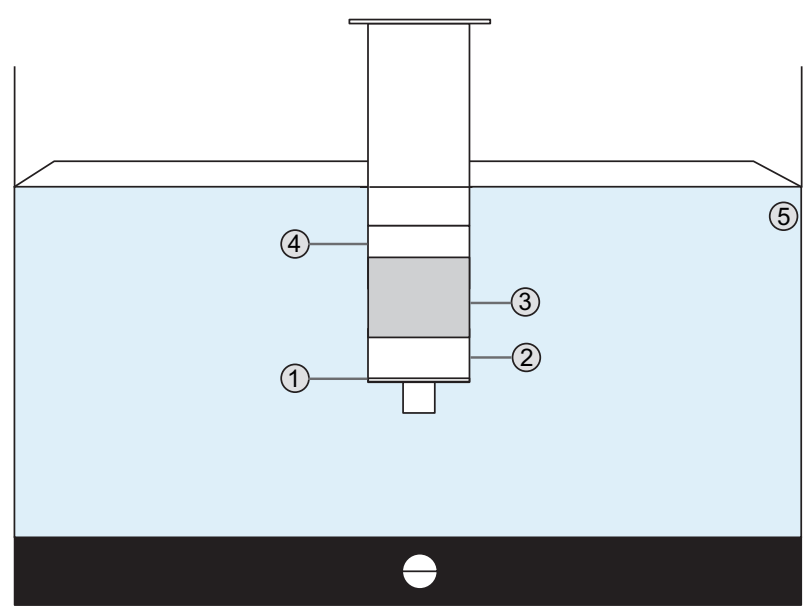

Fig. 1. Extraction system: (1) filter paper; (2) anhydrous sodium sulfite; (3) sample; (4) acetonitrile gradient grade for liquid chromatography, and (5) ultrasound bath

\section{Degradation bioassay of the red California ear- thworm (Eisenia foetida)}

Earthworms were obtained from plant nurseries maintained in the zoology area of the School of Biology of the National University of San Agustín, located in the city of Arequipa. For the present study, adult worms were used (Svobodová et al. 2018, $\mathrm{Xu}$ et al. 2019), which were raised in the Project Mercury research laboratory located at the Catholic University of Santa María (also located in Arequipa), in soils enriched with $10 \%$ of organic material and humidity adjusted to approximately $40 \%$. The degradation runs were developed using a methodology of toxicity studies, present in the soil test established by the Organization for Economic Cooperation and
Development (OECD 1984). Studies of enzymatic activity of Eisenia foetida in the presence of chlorpyrifos work at a concentration of $40 \mathrm{mg} / \mathrm{kg}$ (Wang et al. 2012). On the other hand, the avoidance response test showed significant repellent effects at a chlorpyrifos concentration of $40 \mathrm{mg} / \mathrm{kg}$ (Zhou et al. 2007). Soils were contaminated with chlorpyrifos at a concentration of $40 \mathrm{mg} / \mathrm{kg}$, dissolved in $5 \mathrm{~mL}$ of petroleum ether and later mixed with $150 \mathrm{~g}$ sand in order to be dispersed homogenously throughout the soils under study.

For the degradation study, a factorial design $2^{2}$ (Table I) evaluating the four groups (A, B, C, and $\mathrm{D}$ [control group]) was used. The worms were of the same size $(7.01 \pm 0.17 \mathrm{~cm})$ and sexual maturity. The bioassay was developed in a glass container with 500 $\mathrm{g}$ of contaminated soil and $40 \mathrm{mg} / \mathrm{kg}$ of chlorpyrifos. Group D contained sterilized soil without the presence of worms. Group C contained soil only. Group B consisted of sterilized soil with the presence of 20 individual worms of Eisenia foetida with well-developed clitellums, adding 10 worms to each treatment (Zhou et al. 2007, Hao et al. 2018). Finally, Group A consisted of unsterilized soil with the presence of the same quantity of individual worms as Group B. Samples were taken every seven days for a month, and concentrations of chlorpyrifos were determined by HPLC. The enzyme activity of worms exposed to chlorpyrifos was lower compared to the control and decreased in response to increasing concentrations of chlorpyrifos during the seven days of exposure (Wang et al. 2012). Then, the recognizable symptoms of poisoning disappeared approximately 14 to 21 days after exposure (Aamodt et al. 2007). Sampling was determined after $0,7,14,21$ and 28 days according to the Lin's method (Lin et al. 2018).

TABLE I. FACTORIAL DESIGN OF THE DEGRADATION BIOASSAYS

\begin{tabular}{cccc}
\hline Variables & & Microbiotic flora & Worms \\
\hline \multirow{6}{*}{ Groups } & A & Yes & Yes \\
& B & No & Yes \\
& C & Yes & No \\
& D & No & No \\
\hline
\end{tabular}

\section{Statistical analysis}

Data were plotted using OriginPro (v. 9.0), and the difference between treatments $(\mathrm{p}<0.05)$ was determined by a one-way variance analysis (ANOVA) (Sun et al. 2019) with the Tukey honestly significant 


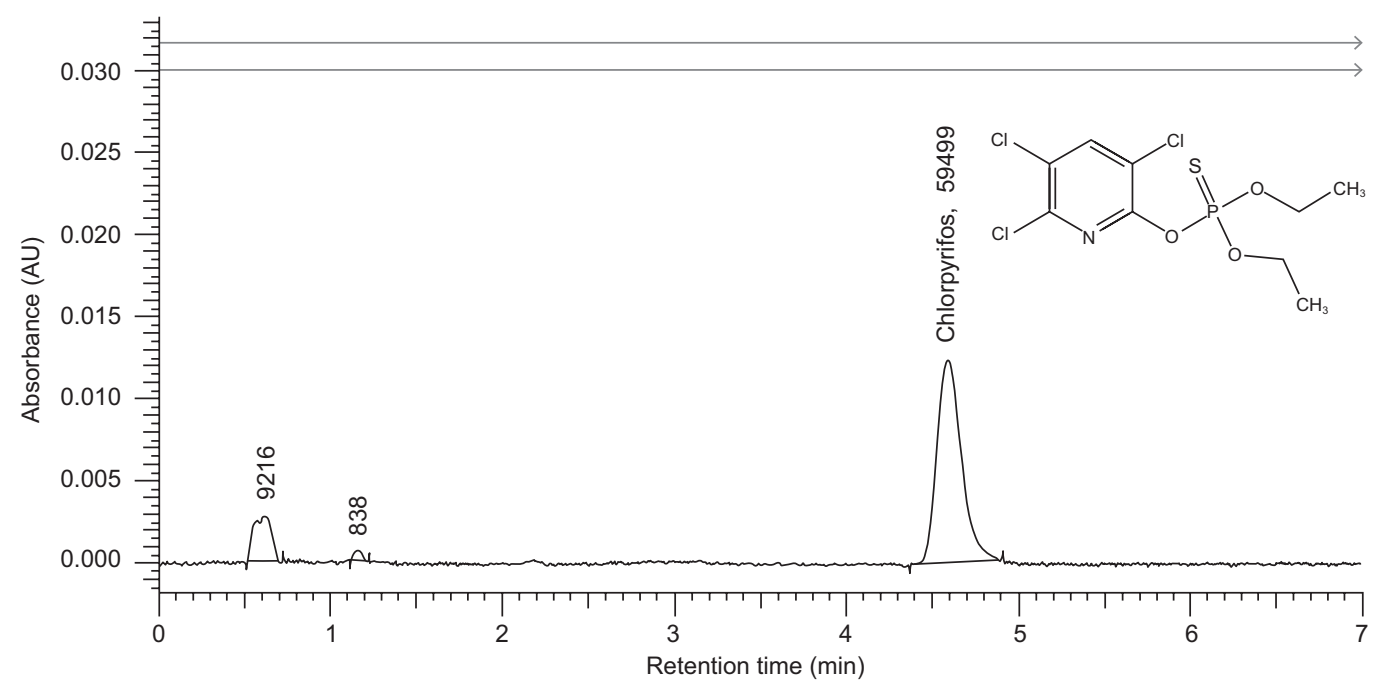

Fig. 2. Chromatogram to $205 \mathrm{~nm}$ corresponding to chlorpyrifos with a retention time of $4.6 \mathrm{~min}$

difference (HSD) multiple comparison test, as well as processing of factorial design data. The cube plot was obtained for more optimal interaction and the Pareto diagram was used to know if the evaluated factors were determinant in the degradation using Minitab 17 software.

\section{RESULTS AND DISCUSSION}

The retention time obtained for chlorpyrifos was 4.6 minutes in already-established conditions (Fig. 2). The method presented a linear correlation between the concentration and its answer, with a determination coefficient $\left(\mathrm{R}^{2}\right)$ of 0.9996 . The quantification (LOD) and detection (LOQ) limits were 0.0795 and $0.0484 \mathrm{mg} / \mathrm{L}$, respectively. The variation-percentage coefficient was $2.25 \%$. Finally, the method recovery percentage was $90.48 \%$ (Table II).

TABLE II. METHOD VALIDATION

\begin{tabular}{cccccc}
\hline & $\mathrm{R}^{2}$ & $\mathrm{CV} \%$ & $\begin{array}{c}\mathrm{LOD} \\
(\mathrm{mg} / \mathrm{kg})\end{array}$ & $\begin{array}{c}\mathrm{LOQ} \\
(\mathrm{mg} / \mathrm{kg})\end{array}$ & $\begin{array}{c}\% \text { de } \\
\text { Recovery }\end{array}$ \\
\hline Chlorpyrifos & 0.9996 & 2.25 & 0.0484 & 0.0795 & 90.48
\end{tabular}

$\mathrm{R}^{2}$ : determination coefficient, $\mathrm{CV} \%$ : coefficient of variation, LOD: limit of detection, LOQ: limit of quantification

\section{Bioassay of chlorpyrifos degradation in soils}

In a previous study conducted by Chen et al. (2014) regarding the acute toxicity $\left(\mathrm{LC}_{50}\right)$ of chlorpyrifos in Eisenia foetida, using OECD for soil during 7 to 14 days as test method, $\mathrm{LC}_{50}$ values for chlorpyrifos of 421.3 and $384.9 \mathrm{mg} / \mathrm{kg}$, respectively, were found.

In table III and figure 3, it can be observed that at the end of the treatment in group A, in which 10 worms and microorganisms interacted, the chlorpyrifos levels diminished by $74.85 \%$ compared to the control group, hence there is a significant reduction. In group $\mathrm{B}$, which only contained 10 worms with sterilized soil (in absence of microorganisms), the degradation was $60.76 \%$. In group $\mathrm{C}$, which contained microorganisms in the absence of Eisenia foetida, a degradation of $32.18 \%$ was identified. Finally, in group D, which contained sterilized soil in the absence of worms, a degradation of $33.68 \%$

TABLE III. PERCENTAGE OF CHLORPYRIFOS DEGRADATION UNTIL DAY 28*

\begin{tabular}{|c|c|c|c|c|}
\hline \multirow{3}{*}{$\begin{array}{l}\text { Time } \\
\text { Days }\end{array}$} & \multicolumn{4}{|c|}{ Degradation } \\
\hline & A & B & $\mathrm{C}$ & $\mathrm{D}$ \\
\hline & $\%$ & $\%$ & $\%$ & $\%$ \\
\hline 0 & 0 & 0 & 0 & 0 \\
\hline 7 & 47.41 & 36.32 & 16.53 & 9.74 \\
\hline 14 & 52.84 & 38.94 & 25.21 & 20.43 \\
\hline 21 & 53.01 & 50.61 & 33.20 & 27.01 \\
\hline 28 & 74.85 & 60.76 & 37.18 & 33.68 \\
\hline
\end{tabular}

*One-way variance analysis $(\mathrm{p}<0.05)$ and the Tukey test demonstrated that significant differences were found between the study groups. F value $(819.373)>$ critical value for $F(4.066)$; $\mathrm{p}$ value: $2.72 \times 10^{-10}(\mathrm{p}<0.05)$

A: Eisenia foetida + native bacteria, B: Eisenia foetida, C: native bacteria, D: control group 
of the aforementioned organophosphorus compound pesticide was observed (Table III).

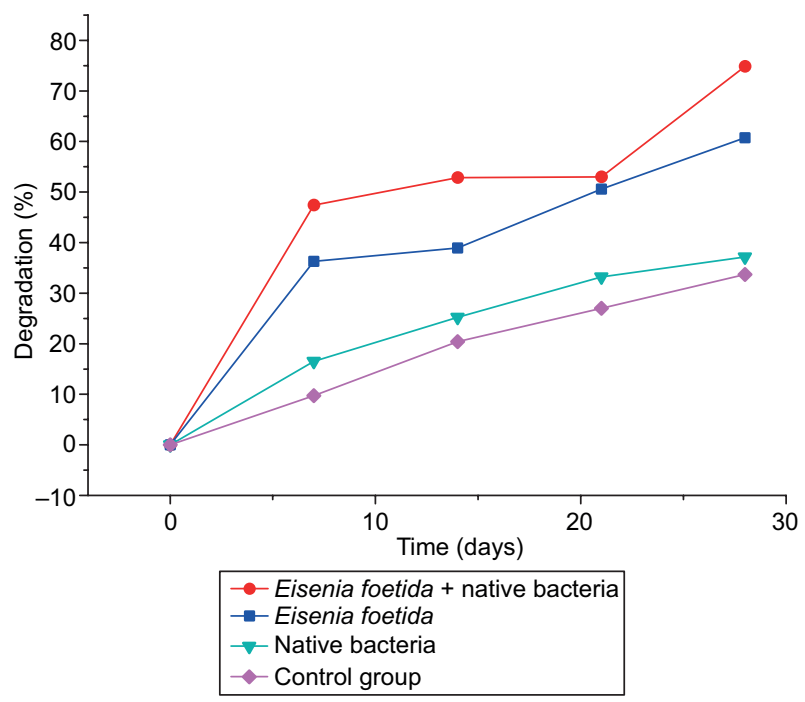

Fig. 3. Chlorpyrifos degradation in groups A (Eisenia foetida + native bacteria), B (Eisenia foetida), C (native bacteria), and D (control group) until day 28

\section{Pesticide degradation in soils self-rehabilitated without worms (target)}

The World Health Organization (WHO) reports that with temperatures up to $25^{\circ} \mathrm{C}$ in centers buffered to $\mathrm{pH}$ levels of 5 and 7, the degradation period of chlorpyrifos is approximately 72 days, and in those buffered to a $\mathrm{pH}$ level of 9, the average lifetime diminishes drastically to 16 days, which is due to the hydrolysis process that directly affects organophosphorus-compound pesticides.

Tay et al. (2010) evaluated the hydrolysis of chlorpyrifos in watery centers buffered in different temperature and $\mathrm{pH}$ conditions, discovering that the average lifetime of chloropyrifos is relatively stable in acidic centers. However, the degradation velocity increased as $\mathrm{pH}$ was elevated ( $\mathrm{pH}$ values of 4, 7 and 10). In a like manner, temperature also had a significant effect regarding the rate of hydrolysis. Tay et al. (2010) demonstrated that starting from a $\mathrm{pH}$ of 7 , the hydrolysis process is more aggressive and follows first-order kinetics.

For this reason, in figure 4 it can be observed that within the target, the concentration level of chlorpyrifos diminishes until reaching a degradation percentage of $33.68 \%$. This could be due to the hydrolysis process since according to Tay et al. (2010) the pH level of soil was reported as 7.051 during the treatment.

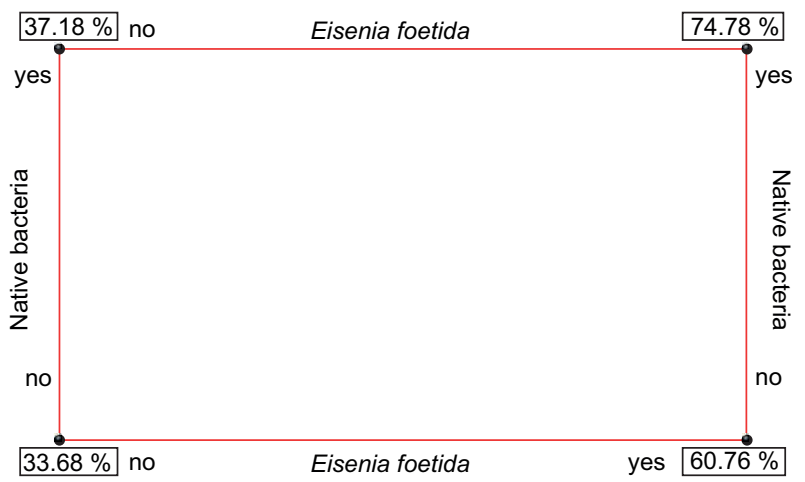

Fig. 4. Cube graphic for the degradation percentage of chlorpyrifos

\section{Degradation assisted by microorganisms}

Swapnil et al. (2012) evaluated the degradation abilities of the bacterial consortium Exiguobacterium sp. $\mathrm{BCH} 4$ and Rhodococcus sp. $\mathrm{BCH} 2$ for the purpose of degrading acephate. It achieved a degradation of $75.85 \%$ in 6 days at an initial concentration of $50 \mathrm{mg} / \mathrm{L}$.

In the present project, a chlorpyrifos degradation of $37.18 \%$ (Fig. 4) was obtained. This result could be directly related to the bacterial activity in the soil; however, one cannot draw a conclusion on the basis that hydrolysis processes play an important role, and according to this the percentage obtained is not necessarily due to bacterial activity but rather to other types of microorganisms or the average lifetime of pesticides.

\section{Performance of Eisenia foetida regarding chlor- pyrifos degradation}

Qixing et al. (2008) evaluated the natural degradation rate of methamidophos in comparison with the activity of Eisenia foetida, such as the presence of copper. They determined that the average lifetime of methamidophos in phaeozem was reduced to 5.08 days when worms were present, suggesting that the result was due to the detoxification effect assisted by the worm Eisenia foetida. The present project succeeded in providing evidence proving that Eisenia foetida could increase the degradation process of the organophosphorus-compound pesticide chlorpyrifos.

In figure 4 it can be seen that Eisenia foetida reduced chlorpyrifos by $60.76 \%$. This performance could be due to the fact that these annelids process the soil for the gathering of humus, involving the alkalinization of the soil in their digestive tracts, thus diminishing $\mathrm{pH}$ levels while achieving an in- 
crease in hydrolysis processes directly affecting the organophosphorus-compound pesticide in question.

Givaudan et al. (2014), whose hypothesis focused on the acclimatization of earthworms to organic chemical products (pesticides), evaluated the adaptive ability of two populations of earthworms (Aporectodea caliginosa), which involved an exposure time of 20 years to organic soil pollutants such as epoxiconazole, a fungicide used worldwide. It was observed that the respiration rate was increased in both worm populations exposed to fungicides in comparison to the control groups. This result may explain why worms are located close to the surface. On the other hand, the glycogen resources were reduced in similar proportions in both populations previously exposed for 28 days. The soluble protein and the majority of the aminoacid content increased only in the population previously exposed, which suggests a detoxification mechanism.

In the present study, worms were obtained from plant nurseries in the city of Arequipa in which the use of insecticides was not reported, and also the worms were acclimatized during the development of the project. As Givaudan et al. (2014) indicate, the period during which the worms acclimatize to a center contaminated with pesticides is 7 to 28 days. This result may shed light on the behavior observed in figure 5, in which it can be observed that the acclimatization period is approximately 12 days. During this time, the respiration of the annelids increases and the glycogen deposits begin to diminish, which causes a likewise decrease in the mobility of the worms. After this time, the degradation increases.

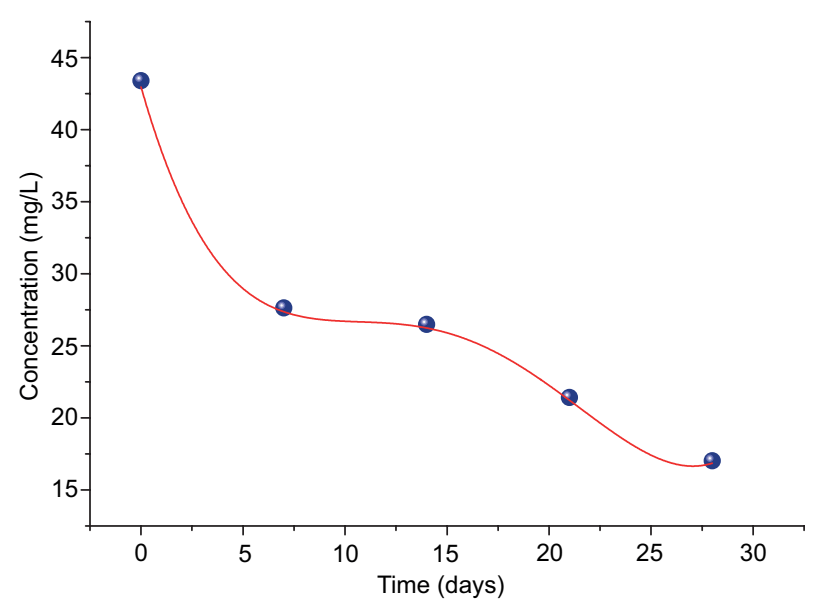

Fig. 5. Degradation of the chlorpyrifos concentration as a function of time in the presence of Eisenia foetida in sterile soils

\section{Performance of Eisenia foetida in the presence of soil microorganisms}

In figure 6 it can be observed that chlorpyrifos degradation in group $\mathrm{A}$, in which there were as many worms as soil microorganisms, was $74.85 \%$. On the other hand, it should be highlighted that if the average effect of the degradation in the presence of Eisenia foetida and native bacteria is evaluated separately, it seems to be affected more by Eisenia foetida. It is likely that Eisenia foetida and native bacteria play a synergistic role in the degradation of chlorpyrifos because studies reveal that the activity of E. foetida favors bacterial growth, promoting greater degradation compared to these two factors when evaluated separately.

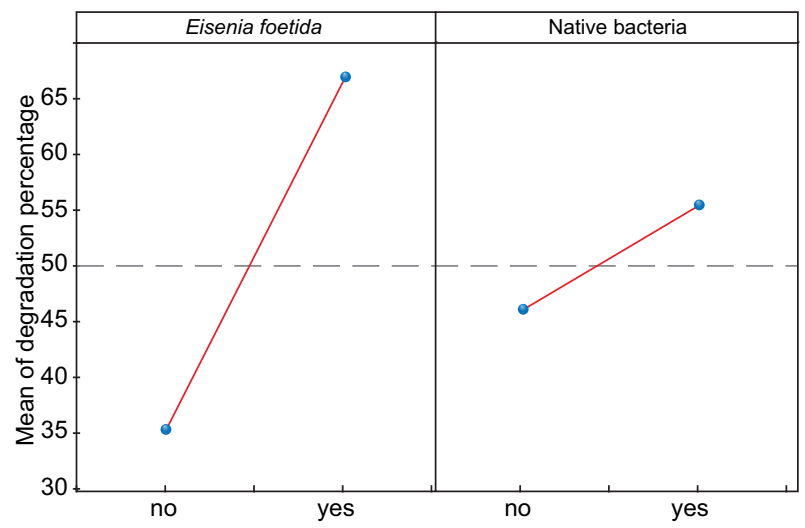

Fig. 6. Average effect of the degradation percentage of chlorpyrifos by Eisenia foetida and native bacteria in soils

Accordingly, in the soil there are not only bacteria involved in the degradation of Chlorpyrifos such as Klebsiellia sp. (Gilani et al. 2010), Acinetobacter sp., Pseudomonas putida, Bacillus sp., Pseudomonas aeruginosa, Citrobacter freundii, Stenotrophomonas sp., Flavobacterium sp., Proteus vulgaris, Pseudomonas sp., Acinetobacter sp., and Proteus sp. (Pino and Peñuela 2011), but also other kinds of microorganisms such as Acremonium sp. (Kulshrestha and Kumari 2011) and Verticillium sp. (Fang et al. 2008). Lu et al. (2014) reported the influence of inoculation with the arbuscular mycorrhizae fungi (AMF) Glomus caledoniun L. and/or earthworms (Eisenia foetida) in phytoremediation processes in soil contaminated with PCB for a rye grass crop during 180 days. In this case, rye-grass plantation, rye grass inoculated with earthworms, with AMF, and co-inoculated with AMF and earthworms, PCB levels diminished by $58.4 \%$, $62.6 \%, 74.3 \%$, and $79.5 \%$ respectively. Clearly, 
it can be observed that Eisenia foetida promotes the degradation activity of this organic pollutant. However, the combination of worms with fungi increases in great measure the velocity of PCB degradation. In the present study, it can be observed that there is also an increase in chlorpyrifos degradation in soils with as many worms as microorganisms present (Table III).

Finally, through the Pareto diagram representing the effects of the factors Eisenia foetida (A) and native bacteria (B), showing their causal relationships with regards to degradation (Fig. 7), it can be appreciated that in both cases the individual factors as well as their combination (AB) do not interfere with the process in a negative way.

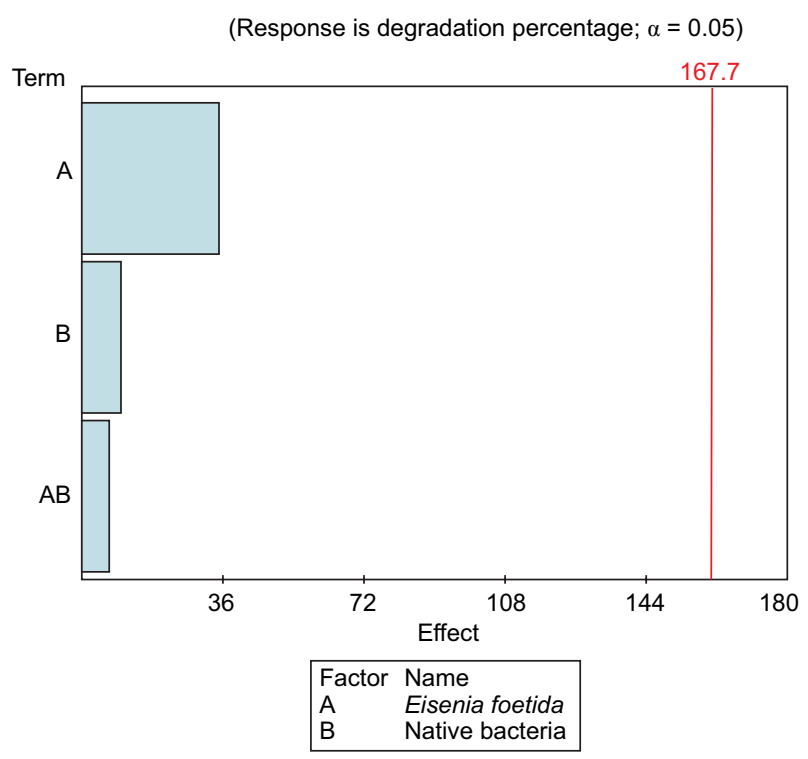

Fig. 7. Pareto diagram for the degradation of chlorpyrifos with effects below the reference red line value of 167.6

\section{CONCLUSIONS}

The current study demonstrates that chlorpyrifos undergoes hydrolysis processes due to the influence of $\mathrm{pH}$ (7.051), degrading over a period of 28 days to $33.68 \%$. The microbial activity of the soil degraded the presence of chlorpyrifos to $37.16 \%$, demonstrating that bacterial activity plays an important role in the degradation process. On the other hand, Eisenia foetida accelerates the degradation process, achieving a degradation percentage of $60.76 \%$ of the chlorpyrifos present in the soil, which strongly indicates that this annelid helps to facilitate the chlorpyrifos degradation process. Finally, Eisenia foetida, in combination with general soil microorganisms, performs a synergistic role relating to the degradation of pesticide, as was proven by the decrease of chlorpyrifos levels to $74.85 \%$ at the end of the treatment.

\section{ACKNOWLEDGMENTS}

The authors would like to express gratitude to Consejo Nacional de Ciencia y Tecnología (CONCYTEC) and, likewise, to Dr. José A. Villanueva Salas for permitting us to develop and execute the experimental part of our research in the Laboratorio del Proyecto Mercurio (H-202), Universidad Católica de Santa María de Arequipa.

\section{REFERENCES}

Aamodt S., Konestabo H.S., Sverdrup L.E., Gudbrandsen M., Reinecke S.A. and Stenersen J. (2007). Recovery of cholinesterase activity in the earthworm Eisenia fetida Savigny following exposure to chlorpyrifos. Environ. Toxicol. Chem. 26 (9), 1963-1967.

DOI: $10.1897 / 07-021 R .1$

Castro J. (2003). Determinación, persistencia y distribución de insecticidas de uso agrícola en el medio ambiente. Doctoral Dissertation. Facultad de Ciencias, Universidad Autónoma de Madrid. Madrid, Spain, $203 \mathrm{pp}$.

Chen C., Wang Y., Zhao X., Wang Q. and Qian Y. (2014). Comparative and combined acute toxicity of butachlor, imidacloprid and chlorpyrifos on earthworm, Eisenia fetida. Chemosphere 100, 111-115. DOI: 10.1016/j.chemosphere.2013.12.023

Fang H., Qian Y., Hao Y., Qiang X., Dong X., Quan J. and Long Y. (2008). Fungal degradation of chlorpyrifos by Verticillium sp. DSP in pure cultures and its use in bioremediation of contaminated soil and pakchoi. Int. Biodeter. Biodegr. 61 (4), 294-303.

DOI: 10.1016/j.ibiod.2007.10.001

Fernández D., Mancipe L. and Fernández D. (2010). intoxicación por organofosforados. Revista Med. 18 (1), 84-92.

DOI: $10.18359 /$ rmed.1295

Gilani S., Ageen M., Shah H. and Raza S. (2010). Chlorpyrifos degradation in soil and its effect on soil microorganisms. J. Anim. Plant Sci. 20 (2), 99-102.

Givaudan N., Wiegand C, Le Bot B., Renault D., Pallois F., Llopis S. and Binet F. (2014). Acclimation of earthworms to chemicals in anthropogenic landscapes, physiological mechanisms and soil ecological implication. Soil Biol. Biochem. 73, 49-58.

DOI: $10.1016 /$ j.soilbio.2014.01.032 
Hao Y., Zhao L., Sun Y., Li X., Weng L., Xu H. and Li Y. (2018). Enhancement effect of earthworm (Eisenia fetida) on acetochlor biodegradation in soil and possible mechanisms. Environ. Pollut. 242 (Pt. A), 728737. DOI: 10.1016/j.envpol.2018.07.029

Hernández-Ruiz G., Álvarez-Orozco N. and Ríos-Osorio L. (2017). Biorremediación de organofosforados por hongos y bacterias en suelos agrícolas: revisión sistemática. Corpoica Cienc. Tecnol. Agropecuaria 18 (1), 139-159.

DOI: $10.21930 /$ rcta.vol18_num1_art:564

Kulshrestha G. and Kumari A. (2011). Fungal degradation of chlorpyrifos by Acremonium sp. strain (GFRC-1) isolated from a laboratory-enriched red agricultural soil. Biol. Fert. Soils 47 (2), 219-225.

DOI: $10.1007 / \mathrm{s} 00374-010-0505-5$

Lin Z., Zhen Z., Ren L., Yang J., Luo C., Zhong L., Hu H., Zhang Y., Li Y. and Zhang D. (2018). Effects of two ecological earthworm species on atrazine degradation performance and bacterial community structure in red soil. Chemosphere 196, 467-475.

DOI: 10.1016/j.chemosphere.2017.12.177

Lu Y., Lu M. Peng F. Wan Y. and Liao M. (2014). Remediation of polychlorinated biphenyl-contaminated soil by using a combination of ryegrass, arbuscular mycorrhizal fungi and earthworms. Chemosphere 106, 44-50. DOI: 10.1016/j.chemosphere.2013.12.089

Majzik-Solymos E., Visi E., Károly G., Beke-Berczi B. and Györfi L. (2001). Comparison of extraction methods to monitor pesticide residues in surface water. J. Chromatogr. Sci. 39 (8), 325-331.

DOI: $10.1093 /$ chromsci/39.8.325

Marín L. and Jaramillo B. (2015). Aislamiento de bacterias degradadoras de pesticidas organofosforados encontrados en suelos y en leche bovina. Rev. Chil. Nutr. 42 (2), 179-185. DOI: $10.4067 /$ S0717-75182015000200010

OECD (1984). Guidelines for the testing of chemicals $\mathrm{N}^{\circ}$ 207. Earthworm, acute toxicity tests. Organization for Economic Co-operation and Development, Paris, France. DOI: 10.1787/9789264070042-en

Qixing Z., Mele Q. and Jidong L. (2008). Ecological detoxification of methamidophos by earthworms in phaiozem co-contaminated with acetochlor and copper. Appl. Soil Ecol. 4 (1), 138-145.

DOI: $10.1016 / \mathrm{j}$.apsoil.2008.03.014

Pino N. and Peñuela G. (2011). Simultaneous degradation of the pesticides methyl parathion and chlorpyrifos by an isolated bacterial consortium from a contaminated site. Int. Biodeter. Biodegr. 65 (6), 827-831.

DOI: $10.1016 /$ j.ibiod.2011.06.001

Quattrocchi O., Abelaria S. and Laba E. (1992). Introducción a la HPLC aplicación y práctica. Artes Gráficas Farro, Buenos Aires, Argentina, 405 pp.
Sánchez Y., Reyes R., Ramos J. and Rodríguez A. (2010). Comportamiento clínico epidemiológico de la intoxicación por organofosforados. Rev. Ciencias Médicas Pinar Río 14 (4), 75-85.

Schaaf A. (2013). Uso de pesticidas y toxicidad: relevamiento en la zona agrícola de San Vicente, Santa Fe, Argentina. Rev. Mex. Cienc. Agríc. 4 (2), 323-331. DOI: $10.29312 /$ remexca.v4i2.1252

Sun Y., Zhao L., Li X., Hao Y., Weng L. and Li Y. (2019). Stimulation of earthworms (Eisenia fetida) on soil microbial communities to promote metolachlor degradation. Environ. Pollut. 248, 219-228.

DOI: 10.1016/j.envpol.2019.01.058

Svobodová M., Smídová K., Hvêzdová M. and Hofman J. (2018). Uptake kinetics of pesticides chlorpyrifos and tebuconazole in the earthworm Eisenia andrei in two different soils. Environ. Pollut. 236, 257-264.

DOI: 10.1016/j.envpol.2018.01.082

Swapnil S., Yogesh B. and Jyoti P. (2012). Biodegradation of acephate using a developed bacterial consortium and toxicological analysis using earthworms (Lumbricus terrestris) as a model animal. Int. Biodeter. Biodegr. 69, 1-9. DOI: 10.1016/j.ibiod.2011.11.013

Tay J., Marinah M. and Norhayati M. (2010). Hydrolysis of chlorpyrifos in aqueous solutions at different temperatures and $\mathrm{pH}$. The Malaysian Journal of Analytical Sciences 14 (2), 50-55.

Torri S., Cabello M. and Lavado R. (2007). Diagnóstico de la calidad de los suelos y su fertilidad para el pecán. In: Producción de pecán en Argentina (Lavado R.S. and Frusso E.A., Eds.). INTA-FAUBA, Buenos Aires, Argentina, pp 1-20.

Wang J., Zhu L., Liu W., Wang J. and Xie H. (2012). Biochemical responses of earthworm (Eisenia foetida) to the pesticides chlorpyrifos and fenvalerate. Toxicol. Mech. Methods 22 (3), 236-241.

DOI: $10.3109 / 15376516.2011 .640718$

Xu H., Bai J., Li W., Zhao L. and Li Y. (2019). Removal of persistent DDT residues from soils by earthworms: A mechanistic study. J. Hazard. Mater. 365, 622-631. DOI: 10.1016/j.jhazmat.2018.11.043

Zapata I., Martínez L., Posada E., González M. and Saldarriaga J. (2017). Efectos de la lombriz roja californiana (Eisenia foetida) sobre el crecimiento de microorganismos en suelos contaminados con mercurio de Segovia, Antioquia. Ciencia e Ingeniería Neogranadina 27 (1), 77-90. DOI: $10.18359 /$ rcin. 1911

Zhou S., Duan C., Fu H., Chen Y., Wang X. and Yu Z. (2007). Toxicity assessment for chlorpyrifos-contaminated soil with three different earthworm test methods. J. Environ. Sci. 19 (7), 854-858. DOI: 10.1016/S1001-0742(07)60142-9 